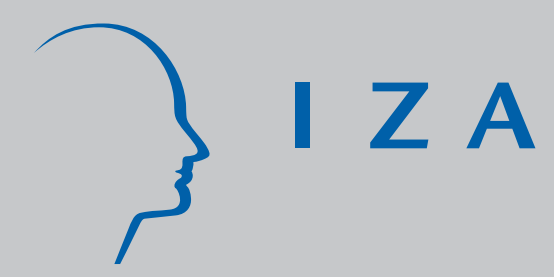

IZA DP No. 935

Performance, Seniority and Wages:

Formal Salary Systems and Individual Earnings Profiles

Thomas J. Dohmen

November 2003 


\title{
Performance, Seniority and Wages: Formal Salary Systems and Individual Earnings Profiles
}

\author{
Thomas J. Dohmen \\ IZA Bonn
}

\author{
Discussion Paper No. 935 \\ November 2003
}

\author{
IZA \\ P.O. Box 7240 \\ D-53072 Bonn \\ Germany \\ Tel.: +49-228-3894-0 \\ Fax: +49-228-3894-210 \\ Email: iza@iza.org
}

\begin{abstract}
This Discussion Paper is issued within the framework of IZA's research area Mobility and Flexibility of Labor. Any opinions expressed here are those of the author(s) and not those of the institute. Research disseminated by IZA may include views on policy, but the institute itself takes no institutional policy positions.
\end{abstract}

The Institute for the Study of Labor (IZA) in Bonn is a local and virtual international research center and a place of communication between science, politics and business. IZA is an independent, nonprofit limited liability company (Gesellschaft mit beschränkter Haftung) supported by Deutsche Post World Net. The center is associated with the University of Bonn and offers a stimulating research environment through its research networks, research support, and visitors and doctoral programs. IZA engages in (i) original and internationally competitive research in all fields of labor economics, (ii) development of policy concepts, and (iii) dissemination of research results and concepts to the interested public. The current research program deals with (1) mobility and flexibility of labor, (2) internationalization of labor markets, (3) welfare state and labor market, (4) labor markets in transition countries, (5) the future of labor, (6) evaluation of labor market policies and projects and (7) general labor economics.

IZA Discussion Papers often represent preliminary work and are circulated to encourage discussion. Citation of such a paper should account for its provisional character. A revised version may be available on the IZA website (www.iza.org) or directly from the author. 
IZA Discussion Paper No. 935

November 2003

\section{ABSTRACT \\ Performance, Seniority and Wages: Formal Salary Systems and Individual Earnings Profiles*}

This paper replicates studies by Medoff and Abraham $(1980,1981)$ and Flabbi and Ichino (2001) using personnel data from the Dutch national aircraft manufacturer Fokker. It shows how a formal salary system, as is widely used by large firms, brings about that seniority-wage profiles are largely independent of controls for reported performance in cross-sectional wage regressions even though supervisors' evaluations shape life-cycle earnings profiles. Performance ratings determine how fast a worker climbs the firm's career and wage ladder. The paper also reveals that real wage growth depends on the employer's prosperity. Furthermore it demonstrates that formal salary systems cause serial correlation in wage growth and 'Green Card' effects.

JEL Classification: $\quad$ M52, J30, J31

Keywords: formal salary systems, returns to seniority, internal labor markets, personnel economics

Thomas J. Dohmen

IZA

P.O. Box 7240

53072 Bonn

Germany

Tel.: +492283894531

Email: dohmen@iza.org

\footnotetext{
* This work has benefited from comments on an earlier draft by Mike Gibbs, Ben Kriechel, Franz Palm, and Gerard Pfann. The suggestions of two anonymous referees have substantially improved the paper. I would like to thank Fokker's bankruptcy trustees, especially Mr. Ben Knüppe, for making the personnel data available. All errors are mine. Financial support from NWO is gratefully acknowledged.
} 


\section{Introduction}

Whether rising seniority-wage profiles during an employment relationship reflect productivity gains or not is one of the most important unresolved questions in labor economics. ${ }^{1}$ Alternative theoretical explanations for a positive relation between firm-specific tenure and earnings have recurrently fuelled this old debate. Crudely, these rival accounts can be dichotomized into theories in which wage profiles reflect productivity profiles and those in which wage changes are unrelated to productivity changes. The former notion is profoundly associated with the human capital explanation. ${ }^{2}$ The latter perspective has been supported by various alternative explanations that rationalize upward-sloping tenure-wage profiles in the absence of on-the-job training or skill accumulation (e.g. the provision of life-cycle incentives, selection and sorting mechanisms, or insurance motives). ${ }^{3}$ A polar way of thinking holds that administrative rules and procedures govern compensation. ${ }^{4}$ But as Mincer (1974) already noted, "“[...] institutional arrangements such as seniority provisions in employment practices [...] do not contradict the productivity-augmenting hypothesis, unless it can be shown that growth of earnings under seniority provisions is largely independent of productivity growth." (op. cit., p.80).

Determining whether upward sloping earnings profiles closely resemble increasing experience-productivity profiles is an empirical challenge that has only rarely been taken up, mainly due to lack of data that simultaneously measure

\footnotetext{
${ }^{1}$ Although there has been much dispute about the size of returns to firm-specific tenure and experience (see e.g. Altonji and Shakotko, 1987; Abraham and Farber, 1987; Topel, 1991), even estimates near the bottom of the range are large enough to justify an inquiry into the causes of such wage growth. A conservative estimate of Altonji and Williams (1997), which meets the criticisms to earlier work, finds, for example, that ten years of tenure raise wages by $11.6 \%$.

${ }^{2}$ See, for example, Becker (1964), Mincer (1962), and Mortensen (1978).

${ }^{3} \mathrm{~A}$ prominent idea is that such a wage structure results from the need to create incentives for workers to provide optimal levels of effort throughout the employment relationship (e.g. Becker and Stigler, 1974; Lazear, 1979; Lazear, 1981; and Lazear and Rosen 1981). Likewise, selection and sorting (Rosen, 1986) or sluggish learning about unknown worker productivity paired with an insurance motive (Harris and Holmstrom, 1982) have been shown to generate upward sloping seniority-wage profiles in optimal labor contracts. Other justifications for wage growth independent of productivity changes include matching (e.g. Jovanovic, 1979a), self-sorting (e.g. Salop and Salop, 1976), and on-the-job search (e.g. Burdett, 1978).

${ }^{4}$ See Doeringer and Piore (1971) for an institutional view of the labor market.
} 
productivity and pay. Probably the most influential empirical work on this issue to date is the work by Medoff and Abraham $(1980,1981)$ in which they used personnel data from large U.S. firms to examine whether higher earnings of more experienced managers and professionals can be rationalized by higher productivity of these more experienced white-collar workers. ${ }^{5}$ For that purpose, Medoff and Abraham (hereafter termed M/A) analyzed whether differences in performance ratings could explain the cross-sectional experience-earnings differentials. They showed that the positive effect of seniority on earnings in crosssectional wage regressions remained largely unaffected after having controlled for performance, and that more experienced workers disproportionately end up in the upper tail of the earnings distribution but not in the upper tail of the performance distribution. ${ }^{6}$ Based on the assumption that their performance measure reflects contemporaneous within-job level productivity, M/A concluded that "there does not appear to be a positive correlation between 'human capital' and performance" (M/A, 1980, p. 714). They defended their crucial assumption against several potential criticisms. They argued, for example, that their performance measure must be strongly related to productivity as they could illustrate that better performance raises the probability of promotion and has a positive impact on the size of wage raises. More recently, Flabbi and Ichino (2001) (hereafter termed F/I) not only replicated M/A's work on a sample of non-managerial employees of a large Italian bank, but also extended M/A's study by considering absenteeism and the number of misconduct episodes as al-

\footnotetext{
${ }^{5}$ Their results have stimulated and influenced much theoretical work (see e.g. Lazear, 1981; Harris and Holmstrom, 1982; Demougin and Siow, 1994; Bernhardt, 1995; and Prendergast, 1993). Other notable empirical studies including Kotlikoff and Gokhale (1992), and Hellerstein and Neumark (1995) have found corroborating evidence showing that productivity exceeds earnings when workers are young and vice versa when they are old. Brown (1989), on the other hand, provides some supporting evidence for the human capital explanation. Exploiting information of the Michigan Panel Survey of Income Dynamics (PSID) he shows that on-the-job training has a positive impact on wages, especially for workers without preentry training requirements and prior experience. Hellerstein, Neumark, and Troske (1999), matching plant-level data on inputs and outputs with individual-level on workers to estimate relative marginal products of workers with different characteristics, find that earnings differentials mirror productivity differentials.

${ }^{6}$ They argue that if wages rose with experience because productivity-enhancing skills were acquired on-the-job, the estimated regression coefficients of skill measures would be driven to zero when performance was controlled for.
} 
ternative productivity indicators. They found corroborating support for M/A's conclusion that seniority profiles do not reflect productivity profiles. Nevertheless, their interpretation of the econometric results remains fragile.

In fact, this paper illustrates that formal rules in the firm's promotion and wage policy can generate the patterns that $\mathrm{M} / \mathrm{A}$ and $\mathrm{F} / \mathrm{I}$ uncover even if earnings profiles reflected productivity profiles. Investigating the relation between wages, experience and performance ratings using personnel data from the Dutch aircraft manufacturer Fokker for white-collar employees, who are comparable to M/A's sample, and blue-collar workers, who have similar characteristics as the sample of non-managerial employees analyzed by F/I, I demonstrate that knowledge of the firm's formal salary system justifies a different interpretation of strikingly similar econometric results. The salary systems for both types of workers consist of different wage scales, in which rules define contractual tenure-wage profiles and wage growth contingent on performance ratings. Each job typically encompasses a handful of salary scales so that the contractual within-job tenure profile is extended upon promotion to a higher scale. ${ }^{7}$ Moreover, upward job transitions are typically associated with advancement on the salary scale ladder as jobs on higher hierarchical levels span higher wage scales.

Three features of the formal salary systems contribute to the finding that the effect of seniority on wages is not affected by controls for performance scores in cross-sectional wage regressions. First, performance scores do not only depend on the job level but also on the salary scale within a job. While better performance ratings increase a worker's chance of climbing the within-job-wage ladder faster, there is a strong tendency for evaluations to fall after such a wage promotion, so that workers in higher wage scales of the same job can be more productive than their less productive colleagues who remained assigned to the lower scale even if their recorded performance rating is identical. Second,

\footnotetext{
${ }^{7}$ Wage ranges for white-collar jobs are set up according to a guide chart system as is developed by the compensation consulting firm Hay Associates. Wage ranges for blue-collar jobs are established by a similar point system. The salary systems follow textbook prescriptions (e.g. Milkovich and Newman, 1999). Job evaluation procedures that determine job wage ranges are illustrated for example in chapter 5 of Milkovich and Newman (1999).
} 
rigid nominal wages lead to an asymmetry in the relation between productivity changes (as reflected by the performance score) and wage changes. A demotion in the salary system, due for example to a deterioration in performance, does not trigger a fall in wages. Third, immediate wage increases associated with performance improvements are small relative to wage increases resulting from the contractual tenure-wage profile. Deferred compensation is an important element of the salary system, but the size of contractual wage growth promises depends on performance.

The remainder of this paper is organized as follows. The next section describes the data. Section 3 explains the formal salary system of the firm in more depth and describes how the firm adjusts its wage policy in response to changing economic conditions. Section 4 replicates the cross-sectional analyses proposed by $\mathrm{M} / \mathrm{A}$ and $\mathrm{F} / \mathrm{I}$ to assess the relation between supervisors' evaluations and earnings. Section 5 explores the impact of performance ratings on individual earnings profiles and shows that evaluation scores determine individual wage mobility over time. Section 6 concludes.

\section{The Firm, Data, and Performance Measures}

The data come from the personnel files of the Dutch national aircraft manufacturer Fokker N.V. and contain detailed information on the work histories of all 17610 workers with permanent work contracts at some time during the period from 1 January 1987 until 15 March 1996. On that day, the firm, distressed by the adverse economic conditions that had affected the entire industry during the first half of the 1990s, filed for bankruptcy. Figure 1 illustrates that demand in the market segment for 40-70 seater and 70-125 seater aircraft, for which the firm produced, collapsed in 1990 (see upper panel). The global slump in aircraft demand was partly a consequence of deregulation in the aviation industry. But the severity of the crisis resulted largely from adverse effects of the Gulf War on the aviation industry, which hit the firm unexpectedly. Employment at 
the firm had grown from 10275 workers in January 1987 to a peak at 12852 in February 1991, an episode during which the number of outstanding orders was rising (cf. lower panel of Figure 1). But in the aftermath of the demand shock and the consequent fall in the stock of outstanding aircraft orders employment was severely reduced in a sequence of downsizing operations, the first of which was announced on 1 March 1991. Only 7141 workers were still employed on the day before the bankruptcy.

Apart from worker characteristics (date of birth, gender, education, marital status), job characteristics (job position, job name, blue-collar vs. white-collar employment), and compensation (nominal wage, hours worked, salary scale and grade, the reason for and the date of any wage contract change), the data record a subjective performance measure that evaluates performance in the previous year. Table 1 provides summary statistics of characteristics of employees paid within the different salary systems for blue-collar workers older than 23 years of age and for white-collar employees. ${ }^{8}$ A comparison of the columns reveals the similarity between white-collar Fokker workers and managers at M/A's company A and between blue-collar Fokker workers and non-managerial workers at the Italian bank studied by F/I.

The performance evaluation procedure at Fokker is very similar to that of the firms described by M/A. Workers are rated once a year by their immediate supervisor on a categorical scale. The 6 performance categories for blue-collar workers and the 5 performance scores for white-collar employees are defined in the annotations to Table 1 . Supervisors' evaluations are reviewed by managers of the next higher hierarchical job level. Ratings are then appraised by the human resource department, which sets guidelines concerning the distribution of scores among workers of an administrative unit and monitors the outcome. If a supervisor deviated too much from the norm, synchronization was achieved by

\footnotetext{
${ }^{8}$ In this paper I will only consider workers remunerated according to either of these salary systems. In fact, there are two additional salary systems, one for blue-collar workers younger than 23 years of age, and another one for recently hired white-collar workers who have not yet been placed into the regular white-collar salary system. These salary systems map out wage profiles that channel into the respective regular salary systems for blue-collar and white-collar workers and are described in more detail by Dohmen (2003).
} 
re-appraising scores in discussions with immediate and second line supervisors.

Figure 2 represents the distribution of performance scores for blue-collar and white-collar workers over time. Although the fraction of workers in the upper performance categories declines somewhat during downsizing - probably due to the large inflow of new employees - the distribution of ratings does not change much from year to year. The stability of the performance score distribution provides some evidence for adherence to the guidelines set by the human resource department. ${ }^{9}$ The Figure also reveals that the performance score distribution is compressed, such that most workers get the median score.

\section{The Wage Policy of the Firm}

\subsection{The Formal Salary Systems}

The salary system that regulates pay for blue-collar workers is illustrated by Figure 3. It consists of ten wage scales (numbered 2 to 11) which comprise up to nine grades that each define one nominal wage contingent on the performance rating. ${ }^{10}$ Blue-collar workers climb one grade each year until they have reached the highest grade of a scale. During this period, their contractual wages rise annually by a fixed amount. ${ }^{11}$ A worker receives additional (less) wage growth if his performance rating improves (deteriorates). ${ }^{12} \mathrm{~A}$ one score improvement in performance triggers on average a wage gain of about $2 \%$, which is less than contractual annual wage increases associated with grade advancement which range from $2.4 \%$ to $3.2 \%$. Having attained the highest wage in a scale, a worker can enjoy further wage growth only upon promotion to a higher scale. In general, workers gain only part of the difference between the highest contractual wages

\footnotetext{
${ }^{9}$ Rules concerning the distribution of ratings limit a supervisor's discretion to award high ratings. Overly generous subjective performance evaluations would raise the firm's wage bill.

${ }^{10}$ Lower wage scales have fewer grades. A wage for the best performance rating (score 6) is only defined for the highest grade of each scale.

${ }^{11}$ Since differences between wages of adjacent grades in a scale are constant, annual percentage raises are higher for workers in lower grades of a scale. This feature of the salary system generates what Baker, Gibbs, and Holmstrom (1994a) call the 'Green Card Effect'.

${ }^{12}$ The wage premium associated with a one score improvement in the performance measure increases slightly towards the higher end of the ranking. It is defined in absolute terms and identical across all grades of a given scale.
} 
of two adjacent wage scales — ranging from $4.4 \%$ to $9.7 \%$ — immediately upon a salary scale promotion, for they are typically placed into a lower grade of the higher scale. The other part, i.e. wage growth until the highest grade of the new scale is reached, takes the form of deferred contractual wage growth. ${ }^{13}$

The remuneration system for white-collar workers, depicted in Figure 4, is organized in scales 12 to 18 and differs slightly from that for blue-collar workers. A minimum and a maximum are defined in each scale as a percentage of the scale-specific reference wage. The minimum wage always amounts to $80 \%$ of this reference wage. The maximum wage escalates in steps of 2 percentage points from $106 \%$ of the reference wage in scale 12 to $118 \%$ of the reference wage in scale 18 so that higher scales span wider wage ranges. ${ }^{14}$ The five different performance evaluation scores determine the attainable wage ceiling within a salary scale's wage range. The wage ceilings for performance scores 1,2 , and 3 are respectively at $80 \%, 90 \%$, and $100 \%$ of the reference wage. The wage ceiling associated with the highest score coincides with the maximum wage of a scale, and the midpoint between this maximum wage and the reference wage marks the highest attainable wage for those with score 4 .

The wage path towards the respective wage ceiling is marked out by annual contractual percentage wage raises. The system is set up in such a way that a worker whose performance rating remains unchanged advances from the minimum wage in a scale to his relevant wage ceiling after six raises. Percentage wage growth is higher the better the performance rating is, and, for a given evaluation score, it is higher the further a worker's current wage is below the relevant wage ceiling. ${ }^{15}$

\footnotetext{
${ }^{13}$ Wage ranges of adjacent scales overlap in a systematic way (see Figure 3: For a given performance score, the wage in the $i^{t h}$ highest grade of scale $X$ lies between the wages in the $(i-1)^{t h}$ and $(i-2)^{t h}$ highest grade of scale $X+1$ in any scale up to scale 6 . In higher scales, the wage in the $i^{\text {th }}$ highest grade of scale $X$ lies between the wages in the $(i-2)^{t h}$ and $(i-3)^{t h}$ highest grade of scale $X+1$. For example, the wage in the highest grade of scale 4 lies between the wages in second highest and third highest grades of scale 5 .

${ }^{14}$ The wage structure is convex. Percentage differences between reference wages of adjacent scales are increasing in scales, rising from a $14.0 \%$ between scales 12 and 13 to $17.5 \%$ between scales 17 and 18 . Wage ranges of adjacent wage scales overlap.

${ }^{15}$ Workers never receive wage raises if they are at or beyond the relevant ceiling. Workers with score 2 receive an annual premium of $3 \%$ of the reference wage if currently paid between 80 to 85 percent of the reference wage and $2 \%$ if their pay is between 85 percent and their
} 
The formal definition of wage growth paths contingent on performance and the distance to the wage ceiling generates serial correlation in wage growth rates. ${ }^{16}$ Two other institutional arrangements in both formal salary systems reinforce this serial correlation pattern. First, zero current wage growth is more likely for workers who did not receive a raise in the previous period because conditional on zero past wage growth it is more likely that a worker has attained the relevant wage ceiling, so that he will not enjoy wage growth in the current period unless he is promoted. Second, wage growth is similar over time for workers who do not change scales, because the amount of contractual wage growth is similar within a particular scale, but differs across scales.

\subsection{The Effect of the Firm's Prosperity on Wages}

Although the economic and financial conditions of Fokker changed dramatically during the analysis period, the firm neither altered the formal structure of its salary system nor changed relative wages within the system. The strict adherence to the formal rule structure of the compensation system helps building trust among workers that the firm keeps its promises of future earnings growth and thus adequately rewards workers for their effort and investments. ${ }^{17}$

To adjust for price level increases, the firm raised all wages of the salary systems by the same percentage amount. ${ }^{18}$ Such adjustments happened 9 times during the observation period (January 1, 1987 - March 14, 1996), including the change on January 1, 1987. Table 2 summarizes the dates when price compen-

wage ceiling of 90 percent of the reference wage. Raises for workers with score 3 amount to $4 \%, 3 \%, 2.5 \%$, or $2 \%$ if they are currently paid respectively between 80 and 85,85 and 90,90 and 95 , or 90 and 100 percent of the reference wage. Percentage wage raises for workers with better scores are even higher.

${ }^{16}$ Serial correlation in wage changes is also found in studies by Lillard and Weiss (1979), Baker, Gibbs, and Holmstrom (1994b) and Gibbs and Hendricks (2001). The finding of such person effects in the wage growth rate of earnings has received wide attention in the recent theoretical literature (see e.g. Gibbons and Waldman, 1999).

${ }^{17}$ In combination with a promotion policy of assigning better performing workers to higher job levels or higher salary scales within a given job level the compensation scheme thus encourages productivity enhancing investments in human capital that are difficult to measure and verify (Prendergast, 1993).

${ }^{18}$ Floors for percentage nominal wage raises of blue-collar workers are determined in a collective bargaining process between national unions and employer federations of metal workers. The firm then follows the policy of changing nominal wages of all workers by the same percentage amount. 
sations come into effect, the associated percentage wage raises, and changes in the consumer price index.

A comparison of the development of nominal wages and consumer prices (see the two rightmost columns of Table 2) reveals that the firm's prosperity affects wages of all workers. Contractual wages tend to rise faster than the consumer price index during expansion. But real contractual wages fall during the period of downsizing due to the nominal freeze of contractual wages from April 1992 until January 1996. Workers who cannot secure contractual wage growth by climbing grades and scales or by improving performance bear annual real wage declines of about $2 \%$ after 1 April 1992. In addition, the firm cut all annual raises by $50 \%$ in January 1995 . Moreover, the annual upward salary scale transition rate fell from $26.8 \%$ during expansion to only $18.2 \%$ during downsizing for bluecollar workers and from $16.1 \%$ to $9.2 \%$ for white-collar workers. A major reason for lower upward wage mobility is the decline in upward job mobility rates during downsizing (see Dohmen, Kriechel, and Pfann, 2004). At the same time, salary scale degradations - although generally rare - become more likely during the downsizing episode. ${ }^{19}$

\subsection{Nominal Rigidity}

A worker who descends in the salary system generally keeps his previous salary that applied to the higher scale. ${ }^{20}$ Nominal wage cuts are extremely rare and occur only in exceptional individual circumstances, in which both parties agree to alter the employment contract. ${ }^{21}$ Such a policy of not cutting nominal wages seems to be widely spread throughout the world as the work by Bewley (1999)

\footnotetext{
${ }^{19}$ More than three quarters of all wage contract changes that entail a salary scale descent (423 for blue-collar and 94 for white-collar workers) occur during downsizing.

${ }^{20}$ Most workers $(87.5 \%$ ) who are placed into a lower scale receive unchanged nominal hourly wages, $8.8 \%$ even experience wage growth - typically because of price compensations that affected all workers. Only a small fraction of workers (3.7\%) endure nominal hourly wage cuts, but these workers usually changed their employment contract with the firm. Falling nominal hourly wages coincide with downward salary scale mobility only in 19 cases.

${ }^{21}$ Most of the 197 nominal wage declines are borne by part-time workers (156) between January 1993 and January 1995; 105 of these contract changes relate to workers at a single plant (ELMO) who renounce previous compensation that was awarded despite working fewer shifts.
} 
and studies based on personnel data (e.g. Baker, Gibbs, and Holmstrom, 1994b; Seltzer and Merrett, 2000; and Gibbs and Hendricks, 2001) suggest. Since nominal wages are not cut even if the salary system would dictate this (e.g. after a degradation in salary scales or performance), some workers' wages exceed the contractual norm or even exceed the salary scale's range, although the firm otherwise adheres strictly to the rules of the formal salary system. ${ }^{22}$ Maybe surprisingly, price compensations documented in Table 2 are also awarded to workers whose nominal wage exceeds the contractual norm. Nevertheless, degradations in the salary system are not inconsequential because they reduce contractually promised deferred wage growth.

\section{The Effect of Supervisors's Evaluations on the Cross-sectional Wage Distribution}

When I replicate the earnings functions results, I find that OLS coefficient estimates of semi-log earnings functions for white-collar Fokker workers (see Table 3) are strikingly similar to those reported by M/A (1980) in their Table II for managers, while the ones for blue-collar Fokker workers (see Table 4) closely resemble the estimates for non-managerial employees of the Italian Bank that F/I (2001) document in their Table 6. All estimations are based on a pooled sample of annual snapshots after performance assessments and contractual raises. ${ }^{23}$ The dependent variable, $\ln$ (real annual full-time equivalent salary), is constructed by deflating nominal annual earnings by the price compensations reported in Table 2 and multiplying by the fraction of full-time contractual hours a person worked during the year. Following M/A and F/I, pre-company experience was constructed as the difference between company-specific tenure and potential experience. ${ }^{24}$

\footnotetext{
${ }^{22}$ Gibbs and Hendricks (2001) also report that the firm they study occasionally pays wages that exceed the salary scale's maximum wage. They attribute this phenomenon to "errors".

${ }^{23}$ It should be noted that parameter estimates on single year cross-sections do not differ in any noteworthy way, and neither do estimates for the subset of the male workforce.

${ }^{24}$ Potential experience is based on a worker's age and educational attainment. The expected age at degree completion is derived from the average number of years it takes to complete
} 
Model (1) demonstrates that higher education levels, firm-specific experience, and pre-company experience raise wages for both types of workers. The returns to education come largely from assignment to higher job levels as a comparison of parameter estimates from model (1) and model (2), which includes job level dummy variables, reveals. ${ }^{25}$

Model (3), which adds controls for performance, shows that the positive relation between experience and earnings is essentially independent of performance. Knowing how the salary systems function, this in not surprising because most of the within-scale wage variation for both types of workers is generated by the contractual within-scale tenure profile and not by variation in performance. Since the formal wage structure limits the instantaneous returns to an improvement in performance, better evaluations can only explain a small fraction of the cross-sectional within-job-level wage dispersion.

Regression model (4) mimics model (3) but uses age instead of potential experience. ${ }^{26}$ Regression model (5) also controls for age but uses salary scale dummies instead of job level dummies. The results underscore that the returns to education come largely from assignment to jobs that span higher salary scales, either on the same or on higher job levels. Part of the return to education might also come from increased chances to reach the top salary scales in a given job faster. Likewise, skills acquired during the employment relation seem to map into higher wages through promotion and job change as the smaller coefficients for firm-specific tenure and age suggest. Improvements in productivity are eventually only rewarded upon job change because the formal salary systems limit wage growth in a particular job.

Despite the close similarity between the results in Tables 3 and 4 and those of M/A or F/I, I do not agree with their conclusion that rising individual earnings profiles do not reflect enhanced productivity of more experienced workers.

\footnotetext{
consecutive education modules defined in the notes to Table 1 .

${ }^{25} \mathrm{Job}$ levels were derived from job transitions and are defined in Dohmen, Kriechel, and Pfann (2004).

${ }^{26}$ It also includes a dummy variable for missing education so that it can be based on more observations. Not including these additional observations does not change the results.
} 
It is clear from knowledge of the salary system that a higher performance rating triggers a wage increase. Cross-sectional wage regressions partly indicate a weaker impact of supervisors' evaluations on earnings profiles because the positive relation between performance and wages is dissociated by nominal rigidity which creates an asymmetry in the relationship between performance changes and wage changes. Whereas performance improvements do trigger wage raises, deteriorated performance ratings do not cause wages to fall so that two (identical) workers with the same job assignment, performance rating, and earnings history currently receive identical wages even though one worker's last evaluation score has fallen.

The main reason for a different interpretation of the OLS estimates is, however, that performance requirements are not only contingent on the job level but also differ across salary scales in the same job - possibly because slightly more demanding tasks are completed by workers placed in higher salary scales of a particular job. This is suggested by the fact that performance ratings frequently fall upon promotion to a higher wage scale. ${ }^{27}$ For blue-collar workers, climbing a wage scale triggers a lower performance rating in $60.8 \%$ of the cases in which the promotion coincides with job change and in $48.8 \%$ of cases in which the job remains the same. The respective figures for white-collar workers are $31.0 \%$ and $20.3 \%$

This peculiar relationship between performance rating changes and wage promotions explains M/A's finding that more senior and higher educated managers are more likely to end up in the upper tail of the wage distribution whereas they are not equally likely to end up in the upper tail of the performance rating distribution. This empirical fact that is derived from a multinominal logit analysis, in which the probability of assignment to a particular performance and salary category is modelled as a function of experience, tenure, and education, also holds true for the sample of white-collar Fokker workers. The analogous

\footnotetext{
${ }^{27}$ One might argue that workers slack off after having earned a promotion. But this seems unlikely as a fall in the performance rating is still associated with a sizable drop in discounted earnings.
} 
multinominal logit analysis for blue-collar Fokker workers reveals that seniority does increases the probability of a higher ranking in the performance distribution but that it increases relatively more the probability of a higher ranking in the distribution of performance rankings. This is in line with F/I's findings for non-managerial employees of the Italian bank. ${ }^{28}$

The parameter estimates from the cross-sectional wage regressions in Tables 3 and 4 should not be interpreted as reflecting unbiased estimates of returns to seniority. The OLS regressions suffer from various potential endogeneity problems that have received wide attention in the scientific debate (see Farber, 1999 for a survey of this literature). If, for example, more productive workers — or higher rated workers for that matter - are more likely to stay with the firm, the returns to firm-tenure are overestimated in the OLS regressions that do not correct for such selection effects. ${ }^{29}$ On the other hand, if workers receive job offers drawn from a stable wage offer distribution and change when a wage offer exceeds their current wage, the estimate of the return to experience will be upward biased. Several econometric techniques - the most prevalent of which is the instrumental variable approach - have been proposed to deal with such problems. Probably the most elegant solution to the problem would be to estimate the parameters of the underlying structural model. However, in the present case, estimation of such deep parameters is not necessary because we can derive the shape of tenure profiles from our knowledge of the formal salary system provided that we can determine transition probabilities to higher wage scales or job levels. The next section discusses how heterogeneous seniority profiles evolve.

\footnotetext{
${ }^{28}$ Following M/A and F/I, I categorized white-collar workers as below-average performers for their job level if their evaluation score was 1 or 2 , as average performers if the rating was 3 and as above-average performers if their rating was higher than 3. Next, I assigned them to three salary categories based on worker's percentile ranking in the relevant within-job-level wage distribution, where the quantiles were chosen to mimic the splitting up of the performance rating distribution. The same procedure was used to assign blue-collar workers to performance and salary categories but four categories were defined. The effect of education, potential precompany experience, and company tenure on the probability of an individual's being in each of the salary categories and each of the performance categories was then estimated by maximum likelihood.

${ }^{29}$ Dohmen and Pfann (2003), using the same data, find indeed that workers with poor performance ratings are more likely to separate.
} 


\section{The Longitudinal Relation between Performance and Earnings Profiles}

The cross-sectional evidence documented in the previous section might encourage someone to conclude that the implied increasing seniority-wage profiles do not reflect upward-sloping productivity profiles. But there is evidence from wage dynamics over time that higher earnings of more senior workers mirror higher productivity. In fact, heterogeneous experience-earnings profiles result from productivity differences because the steepness of individual earnings profiles depends on performance ratings.

Better performance scores increase the probability of being promoted both to a higher salary scale within the same job and to a higher job level, so that higher rated workers proceed on steeper wage growth paths. White-collar workers rated "very good" are $12.1 \%$ more likely to be promoted to a higher scale than their colleagues who are rated "good", and $21.9 \%$ more likely than those rated "satisfactory". ${ }^{30}$ Ninety percent of white-collar employees who proceed to a higher salary scale are promoted before they have reached the wage ceiling in their current salary scale and higher rated workers tend to proceed earlier: prepromotion salaries of white-collar workers rated "very good" were on average $10.2 \%$ below their wage ceiling and workers rated "good" were on average $9.0 \%$ below their wage ceiling, while the few workers who proceed to a higher salary scale despite a performance score lower than 3 already earned wages exceeding the performance-score-specific wage ceiling.

By promoting higher rated workers before they reach the top of a scale, the firm keeps their outstanding contractual future wage growth on a high level. Considerable life-cycle earnings gains are associated with a promotion, but the largest part of these gains takes the form of extended and steeper wage-tenure profiles, i.e. part of the gains of a promotion is deferred to the future. ${ }^{31}$ The

\footnotetext{
${ }^{30}$ Gibbs (1995) finds comparable results for the relationship between performance and promotion probabilities for the firm studied extensively by Baker, Gibbs, and Holmstrom (1994a and 1994b).

${ }^{31}$ Several studies — among them Baker, Gibbs, and Holmstrom (1994a), Treble, Barmby,
} 
size of contractually future wage raises, i.e. the steepness of life-cycle earnings profiles, therefore depends on performance.

Similarly, the instantaneous wage gain associated with a salary scale promotion is relatively small for blue-collar workers - averaging $4.6 \%$ - but the size of deferred contractual wage raises increases on average from $4.4 \%$ to $6.8 \%{ }^{32}$ Again, a probit analysis reveals that higher rated workers advance earlier before reaching the highest grade of their current scale. Coefficient estimates of two probit models for the promotion prospects of two different groups of blue-collar workers are displayed in Table $5{ }^{33}$ The column labelled "Early Transition" shows estimates for the sub-group of blue-collar workers who have not yet reached the top grade of their salary scale. Being rated "good-very good" improves the promotion probability by $15.9 \%$ relative to the modal rating "normal-good". The column labelled "Late Transition" reports the estimated effects for workers who are already in the top grade of a scale. Performance evaluations have a minor impact on their transition probabilities. But having progressed a wage scale in the previous year raises current promotion chances considerably, implying that workers in the highest grade of a scale are either fast movers (those who were immediately promoted to the top grade from a lower salary scale last year are likely to be promoted again this year to a yet higher salary scale) or are workers who have little hope for further advancement. ${ }^{34}$

Bridges, and van Gameren (2001), or Lluis (2002) - have documented that wage growth at promotion is higher than without but that it is lower than the average difference in wage growth between adjacent job levels. Obviously, this conclusion is also drawn from the Fokker data since upward job transitions typically involve promotion to a higher salary scale and since higher job levels comprise higher salary scales. However, no other study to date has reported evidence about the size of increases in contractually deferred compensation that is associated with a promotion.

${ }^{32}$ Several studies - among them Baker, Gibbs, and Holmstrom (1994a), Treble, Barmby, Bridges, and van Gameren (2001), or Lluis (2002) - have documented that wage growth at promotion is higher than without but that it is lower than the average difference in wage growth between adjacent job levels. Obviously, this conclusion is also drawn from the Fokker data since upward job transitions typically involve promotion to a higher salary scale and since higher job levels comprise higher salary scales. However, no other study to date has reported evidence about the size of increases in contractually deferred compensation that is associated with a promotion.

${ }^{33}$ The coefficient estimates from the probit model in Table 5 are very similar, yet slightly smaller in absolute value, if the analysis is restricted to those who stay in the same job.

${ }^{34}$ Evidence on promotion fast-tracks is also found by Baker, Gibbs, and Holmstrom (1994a); Ariga, Ohkusa, and Brunello (1999); Seltzer and Merrett (2000); Treble, Barmby, Bridges, and van Gameren (2001); and Lin (2002). 
Managing the magnitude of contractually promised future earnings growth seems to be a building block of the firm's wage policy. Rewarding for better performance and deferring compensation to future periods are two important and not necessarily conflicting elements of the firm's wage policy which combines different components, probably to accomplish multiple aims like the retention of able workers and the motivation of employees to become more productive. ${ }^{35}$ However, evidence that part of the promotion wage gain is contractually deferred to future periods necessitates a careful interpretation and estimation of learning effects from data on job and earnings dynamics when only changes in actual wages are recorded. ${ }^{36}$

Individual seniority-wage profiles are shaped by the contractual within-salary scale tenure profile, opportunities to climb salary scales within a job (i.e. the number of salary scales spanned by a job), job transitions and individual performance which impacts both on the probability of climbing a salary scale within a job and the prospects of transitions to jobs that span higher salary scales. Assembly workers in aircraft construction, who constitute the largest job code accounting for about $8 \%$ of blue-collar jobs, can advance from salary scale 5 to 8 (Figure 3 shows how this translates into wage ranges). Other jobs span lower or narrower wage ranges. For example, pay for those who assemble electrical parts, is bound by scales 4 and 6 .

To illustrate how heterogeneous tenure profiles evolve for workers who start on the same job, I consider the example of assembly workers in aircraft construction. An assembly worker who starts in the lowest grade of scale 5 can advance to the highest grade in scale 8 after eight years provided his performance rat-

\footnotetext{
${ }^{35}$ Deferring some of the promotion wage gain to the future, the firm retains some power to adjust future earnings downward when performance deteriorates. This is important since the firm's policy of not cutting nominal wages prevents downward adjustments otherwise.

${ }^{36}$ For example, Lluis (2002) uses data from the German Socio-Economic Panel (GSOEP) and employs an econometric technique proposed by Gibbons, Katz, and Lemieux (1997) and Gibbons, Katz, Lemieux, and Parent (2002) to estimate the Gibbons and Waldman (1999a) model of promotion and wage dynamics. She concludes that evidence that there is no evidence that learning about workers' unobserved ability generates mobility across job levels. However, the data might lead astray because wage innovations do not take into account changes in deferred compensation and thus do not reflect changes in conditional expectations of ability, i.e. the learning process, properly.
} 
ings remain sufficiently high. On such a path, a worker initially proceeds to the second lowest grade in scale 5, and receiving a performance evaluation score of 4 he is promoted to the third lowest grade in scale 6 after his second year of tenure. Upon promotion to a higher scale, a worker is commonly placed into the lowest grade for which the wage exceeds what a worker would have earned if he had only proceeded along the contractual tenure wage path in the lower grade. Typically the worker's performance rating falls upon this transition, but after it has improved again - say after the second year in the scale - the worker might be promoted to scale 7 , where he starts to climb the within-salary scale grade ladder. If the worker's performance enhances beyond score 4 , he is likely to be promoted to scale 8 before reaching the highest grade in scale 7 . In that exceptional case he might even jump one wage grade in scale 8 , thus reaching the top grade of scale 8 after eight years. If performance ratings are less favorable, it takes longer for workers to reach the within-job wage ceiling. Assembly workers whose performance rating is lower than score 3 never proceed to a higher salary scale. A probit analysis reveals that high performance ratings have a particular strong positive impact on early promotion chances of workers in the bottom grades of a salary scale. Moreover, higher performance ratings become generally more important for promotions to the top salary scale of a job. In order to proceed beyond salary scale 8, an assembly worker has to advance to a job with a higher pay range. Such a job change might either involve a transition to a higher job level, for example by becoming a team leader of an assembly group and thereby extending the potential wage range to salary scale 10, or a lateral job change - a quality controller of an assembly line, for example, can proceed to salary scale 9 .

Heterogeneity in earnings dynamics might be informative about ability differences among workers if ability determines the rate at which workers enhance their skills. If more able workers learn faster, i.e. accumulate skills at a higher rate, they are likely to climb the within-job wage ladder faster and are likely 
to be promoted faster. ${ }^{37}$ This causes heterogeneous experience profiles even if observed measures such as schooling degrees or years of experience are the same. This mechanism implies at the same time that past wage growth predicts promotions. To test this hypothesis, I introduced the amount of real contractual wage growth that a worker hired into the blue-collar salary system secures in the first three years of the employment relation as an explanatory variable in a probit model that estimates the probability of being promoted to a higher hierarchical job level in the fourth through sixth year of the employment relation conditional on having stayed with the firm for at least for three years. The coefficient estimates, which are not displayed here, reveal that early career wage growth strongly raises a blue-collar worker's probability of being promoted to a higher job level. ${ }^{38}$

\section{Conclusion}

It has been shown that the institutional rules of formal salary systems, which commonly characterize the wage policies of large firms, make the observed positive relation between seniority and earnings appear to be largely independent of performance ratings in standard cross-sectional wage regressions despite the fact that better performance leads to considerably higher life-cycle earnings. Several features cause this deception. Firstly, the performance evaluation is not only contingent on the job level, but also depends on the contemporaneous assignment to a salary scale within the job's wage range. Performance ratings tend to fall upon advancement to a higher scale. This does not only suggest that performance requirements are more stringent in higher salary scales but

\footnotetext{
${ }^{37}$ Gibbons and Waldman (1999) build on this mechanism to explain Baker, Gibbs, and Holmstrom's (1994a, 1994b) findings that wage growth rates are serially correlated and that past wage growth rates predict promotions.

${ }^{38}$ Estimation results are available from the author upon request. The results for whitecollar workers are similar but not as precisely estimated because only a few workers are hired into the regular white-collar salary system. Most new white-collar employees enter into the preliminary salary system. For these workers the effects are also comparable in size and statistically significant. Higher educational degrees also raise promotion prospects. Moreover, promotion prospects are generally poorer for later cohorts because promotion rates fall during downsizing (see Dohmen, Kriechel, and Pfann, 2004).
} 
also means that two workers with an identical score in the same job might have the same contemporaneous performance rating even though the more productive of the two earns more being assigned to a higher salary scale because of better performance in the past. Secondly, nominal wage rigidity creates an asymmetric relation between transitions in the salary system and wage changes. Promotions, typically initiated by high ratings, result in wage increases while degradations in the salary system, which commonly result from worsened performance, do not have wage consequences. Thirdly, higher performance ratings increase promotion prospects, but much of the life-cycle earnings gain associated with a promotion is neglected in cross-sectional analyses because the largest chunk of the discounted value of a promotion takes the form of contractual entitlements to future wage raises. While better performance increases and prolongs life-cycle earnings growth, wage gains resulting from better performance only accrue gradually with tenure.

Deferred compensation is thus an important element of the wage policy, but upward-sloping tenure profiles are not a mere reflection of institutional seniority provisions. Instead, the sized of contractually promised future wage growth depends on performance, and performance ratings determine the steepness of individual wage-tenure profiles. Such a salary system with a deferred compensation component is likely to encourage workers to make productivity enhancing investments that are difficult to verify as it creates confidence among workers that they will be rewarded for improving their productivity, and it is likely to reduce turnover. That the firm strictly adheres to the formal rule structure even during periods of adverse economic conditions underscores that reliability, trust, and reputation are crucial elements of the wage policy.

\section{References}

Abraham, K. G., and H. S. Farber (1987): "Job Duration, Seniority, and Earnings," American Economic Review, 77(3), 278-297. 
Altonji, J. G., and R. A. Shakotko (1987): "Do Wages Rise with Job Seniority?," Review of Economic Studies, 54(3), 437-459.

Altonji, J. G., and N. Williams (1997): "Do Wages Rise with Seniority? A Reassessment," NBER Working Paper no. 6010.

Ariga, K., Y. Ohkusa, and G. Brunello (1999): "Fast Track: Is it in the Genes? The Promotion Policy of a Large Japanese Firm," Journal of Economic Behavior and Organization, 38(4), 385-402.

Baker, G., M. GibBs, and B. Holmstrom (1994a): "The Internal Economics of the Firm: Evidence from Personnel Data," Quarterly Journal of Economics, 109(4), 881-919.

(1994b): "The Wage Policy of a Firm," Quarterly Journal of Economics, 109(4), 921-955.

Becker, G. S. (1964): Human Capital. NBER, New York.

Becker, G. S., And G. Stigler (1974): "Law enforcement, Malfeasance and Compensation of Enforcers," Journal of Legal Studies, 3(1), 1-18.

Bernhardt, D. (1995): "Strategic Promotion and Compensation," Review of Economic Studies, 62(2), 315-399.

Bewley, T. F. (1999): Why wages don't fall during a recesssion. Harvard University Press, Cambridge, MA.

Brown, J. N. (1989): "Why Do Wages Increase with Tenure? On-the-Job Training and Life-Cycle Wage Growth Observed within Firms," American Economic Review, 79(5), 971-991.

Burdett, K. (1978): "A Theory of Employee Job Search and Quit Rates," American Economic Review, 68(1), 212-220.

Demougin, D., And A. Siow (1994): "Careers in Ongoing Hierarchies," American Economic Review, 84(5), 1261-1277.

Doeringer, P. B., ANd M. J. Piore (1971): Internal Labor Markets and Manpower Analysis. Heath Lexington Books, Lexington, MA.

Dohmen, T. J. (2003): Internal Labor Markets: Theory and Evidence at the Firm Level. Universiteire Pers Maastricht, Maastricht, The Netherlands.

Dohmen, T. J., B. Kriechel, and G. A. Pfann (2004): "Monkey Bars and Ladders: The Importance of Lateral and Vertical Movements in Internal Labor Market Careers," Journal of Population Economics, forthcoming.

Dohmen, T. J., and G. A. Pfann (2003): "Worker Separations in a Nonstationary Corporate Environment," European Economic Review, forthcoming.

FARBER, H. S. (1999): "Mobility and Stability: The Dynamics of Job Change in Labor Markets," in Handbook of Labor Economics, ed. by O. C. Ashenfelter, and D. Card, vol. 3B, pp. 2439-2483, Amsterdam, The Netherlands. Elsevier Science. 
Flabbi, L., And A. IChino (2001): "Productivity, Seniority and Wages: New Evidence from Personnel Data," Labour Economics, 8(3), 359-387.

Gibbons, R., L. Katz, and T. Lemieux (1997): "Learning, Comparative Advantage, and the Inter-Industry Wage Structure," Mimeo, Université de Montreal.

Gibbons, R., L. Katz, T. Lemieux, and D. Parent (2002): "Comparative Advantage, Learning, and Sectoral Wage Determination," NBER Working Paper 8889

Gibbons, R., and M. Waldman (1999): "A Theory of Wage and Promotion Dynamics Inside Firms," Quarterly Journal of Economics, 114(4), 1321-1358.

(1999a): "A Theory of Wage and Promotion Dynamics Inside Firms," Quarterly Journal of Economics, 114(4), 1321-1358.

GibBs, M. (1995): "Incentive Compensation in a Corporate Hierarchy," Journal of Accounting and Economics, 19(2-3), 247-277.

GibBs, M., And W. Hendricks (2001): "Are Formal Salary Systems a Veil?," Working Paper, University of Chicago.

Harris, M., And B. Holmstrom (1982): "A Theory of Wage Dynamics," Review of Economic Studies, 49(3), 315-333.

Hartog, J., G. A. Pfann, and G. Ridder (1989): "(Non-)graduation and the Earnings Function: An Inquiry on Self-Selection," European Economic Review, 33(7), 1373-1395.

Hellerstein, J. K., and D. Neumark (1995): "Are Earnings Profiles Steeper than Productivity Profiles: Evidence from Israeli Firm-Level Data," Journal of Human Resources, 30, 89-112.

Hellerstein, J. K., D. Neumark, and K. R. Troske (1999): "Wages, Productivity, and Worker Characteristics: Evidence from Plant-Level Productions Functions and Wage Equations," Journal of Labor Economics, 17(3), $409-446$.

Kotlikoff, L. J., And J. Gokhale (1992): "Estimating a Firm's AgeProductivity Profile Using the Present Value of Workers's Earnings," Quarterly Journal of Economics, 107(4), 1215-1242.

LAZEAR, E. P. (1979): "Why is There Mandatory Retirement?," Journal of Political Economy, 87(6), 1261-1284.

(1981): "Agency, Earnings Profiles, Productivity, and Hours Restrictions," American Economic Review, 71(4), 606-620.

Lazear, E. P., and S. Rosen (1981): "Rank-Order Tournaments as Optimum Labor Contracts," Journal of Political Economy, 89(5), 841-864.

Lillard, L., AND Y. Weiss (1979): "Components of Variation in Panel Earnings Data: American Scientists 1960-70," Econometrica, 47(2), 437-454. 
LiN, M.-J. (2002): "Opening the Black Box - the Internal Labor Markets of Company X," Working Paper, Essay Two (Thesis Core), University of Chicago.

Lluis, S. (2002): "The Role of Comparative Advantage and Learning in Wage Dynamics and Intra-Firm Mobility: Evidence from Germany," .

Medoff, J. L., and K. G. Abraham (1980): "Experience, Performance, and Earnings," Quarterly Journal of Economics, 95(4), 703-736.

(1981): "Are Those Paid More Really More Productive? The Case of Experience," Journal of Human Resources, 16(2), 186-216.

Milkovich, G. T., And J. M. Newman (1999): Compensation. McGraw-Hill, 6 th edn.

Mincer, J. (1962): "On-the-Job Training: Costs, Returns and Some Implications," Journal of Political Economy, 66(4), 281-302.

- (1974): Schooling, Experience, and Earnings. NBER, New York.

Mortensen, D. T. (1978): "Specific Capital and Labor Turnover," Bell Journal of Economics, 9(2), 572-586.

Prendergast, C. (1993a): "The Role of Promotion in Inducing Specific Human Capital Acquisition," Quarterly Journal of Economics, 108(2), 523-534.

Rosen, S. (1986): "Prizes and Incentives in Elimination Tournaments," American Economic Review, 76(4), 701-715.

Salop, J., and S. Salop (1976): "Self-Selection and Turnover in the Labor Market," Quarterly Journal of Economics, 90(4), 619-627.

Seltzer, A., and D. Merrett (2000): "Personnel Policies at the Union Bank of Australia: Evidence form the 1888-1900 Entry Cohorts," Journal of Labor Economics, 18(4), 573-613.

Topel, R. H. (1991): "Specific Capital, Mobility, and Wages: Wages Rise with Job Seniority," Journal of Political Economy, 99(1), 145-176.

Treble, J., T. Barmby, S. Bridges, and E. van Gameren (2001): "The Internal Economics of The Firm: Further Evidence From Personnel Data," Labour Economics, 8(5), 531-552. 
Figure 1: Aircraft Demand and Employment Dynamics
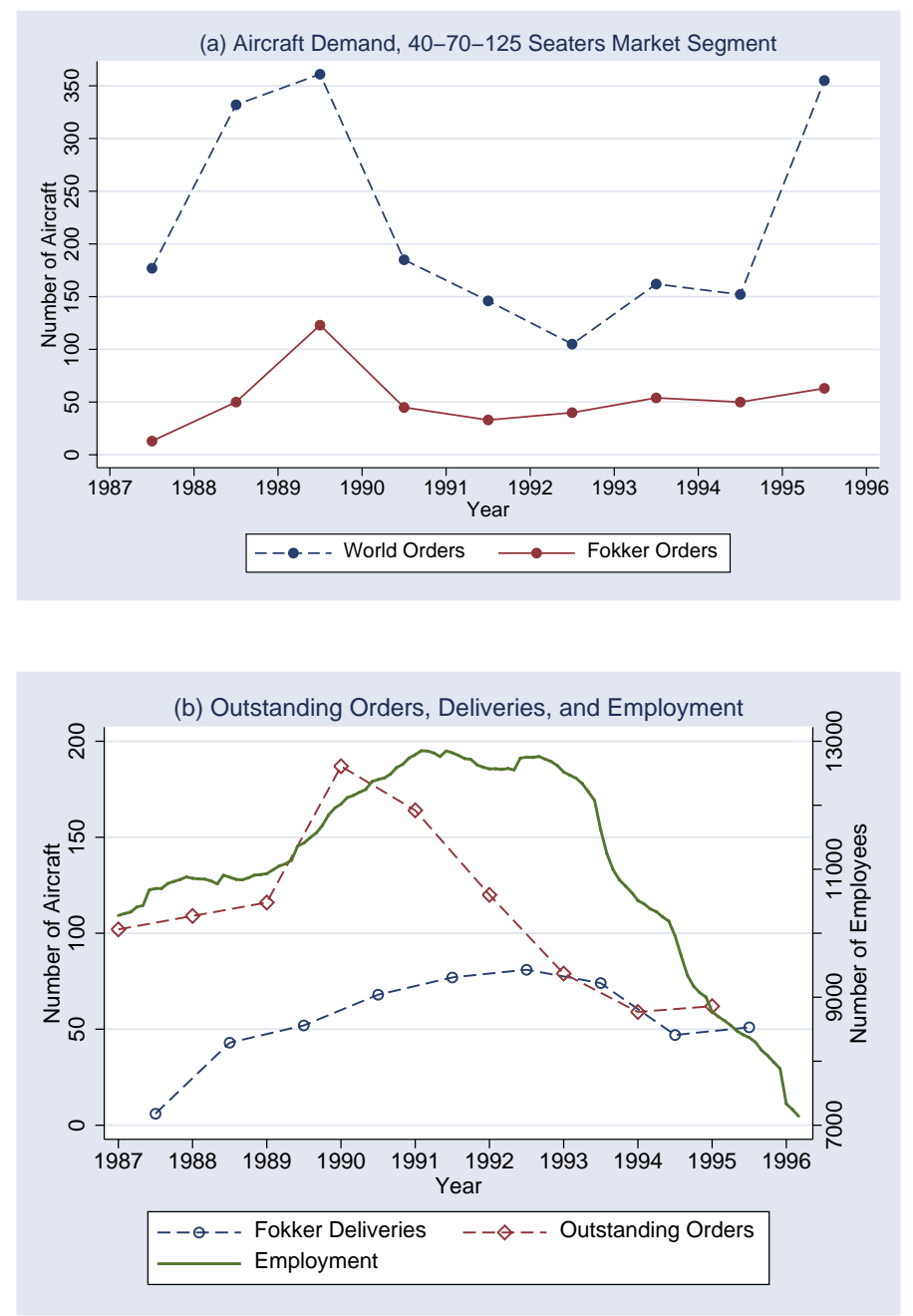

Notes: Panel (a) shows the total number of world aircraft orders and orders for Fokker aircraft in the combined market segments for 40-70 seater and 70-125 seater aircraft. Orders do not include options on 127 Fokker 100, which were placed in 1989 to be exercised in the 1990s but which were later cancelled. Panel (b) plots the number of delivered aircraft, the number of outstanding orders (not including options) at the beginning of the year, and the number of workers with a permanent contract employed at the beginning of each month from January 1987 until March 1996. 
Figure 2: Performance Ratings over Time

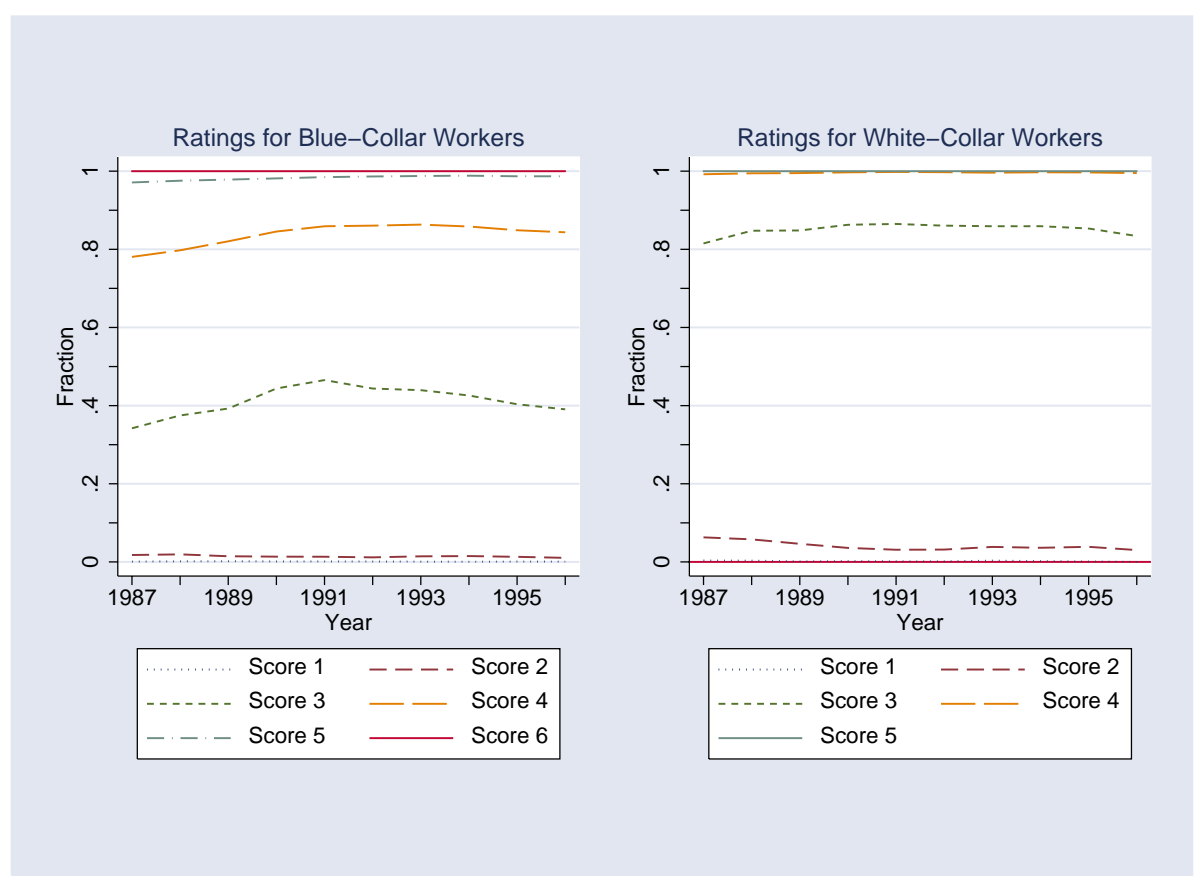

Notes: The Figure shows the distribution of performance ratings for blue-collar and white-collar workers over time. The distance between two lines gives the fraction of workers who obtained a score equal to the label of the upper line. 
Figure 3: The Salary System for Blue-Collar Workers

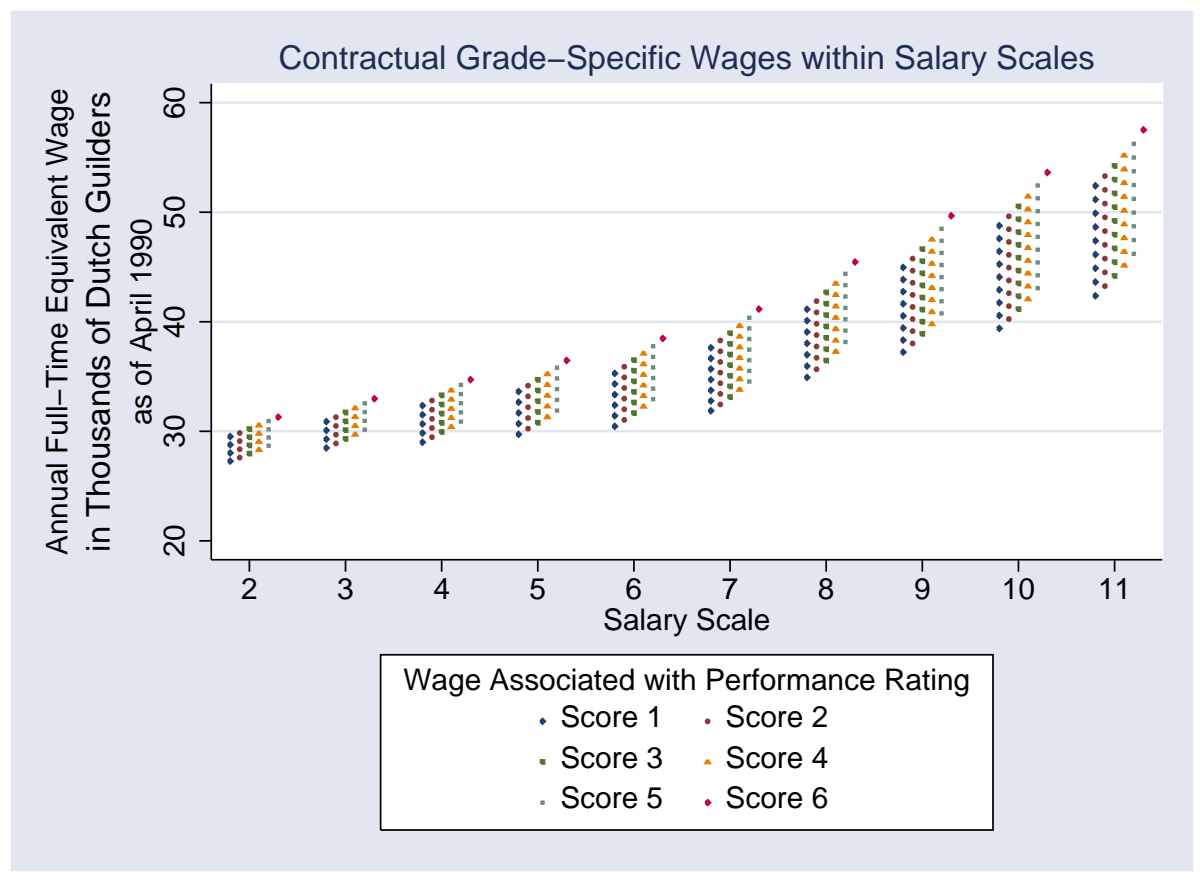

Notes: The Figure plots contractual annual full-time equivalent wages that are defined in the salary system for blue-collar workers. Each mark represents a wage. Vertically aligned marks represent the wages associated with the different grades which constitute the contractual tenure profile for a given performance rating in a salary scale. 
Figure 4: The Salary System for White-Collar Workers

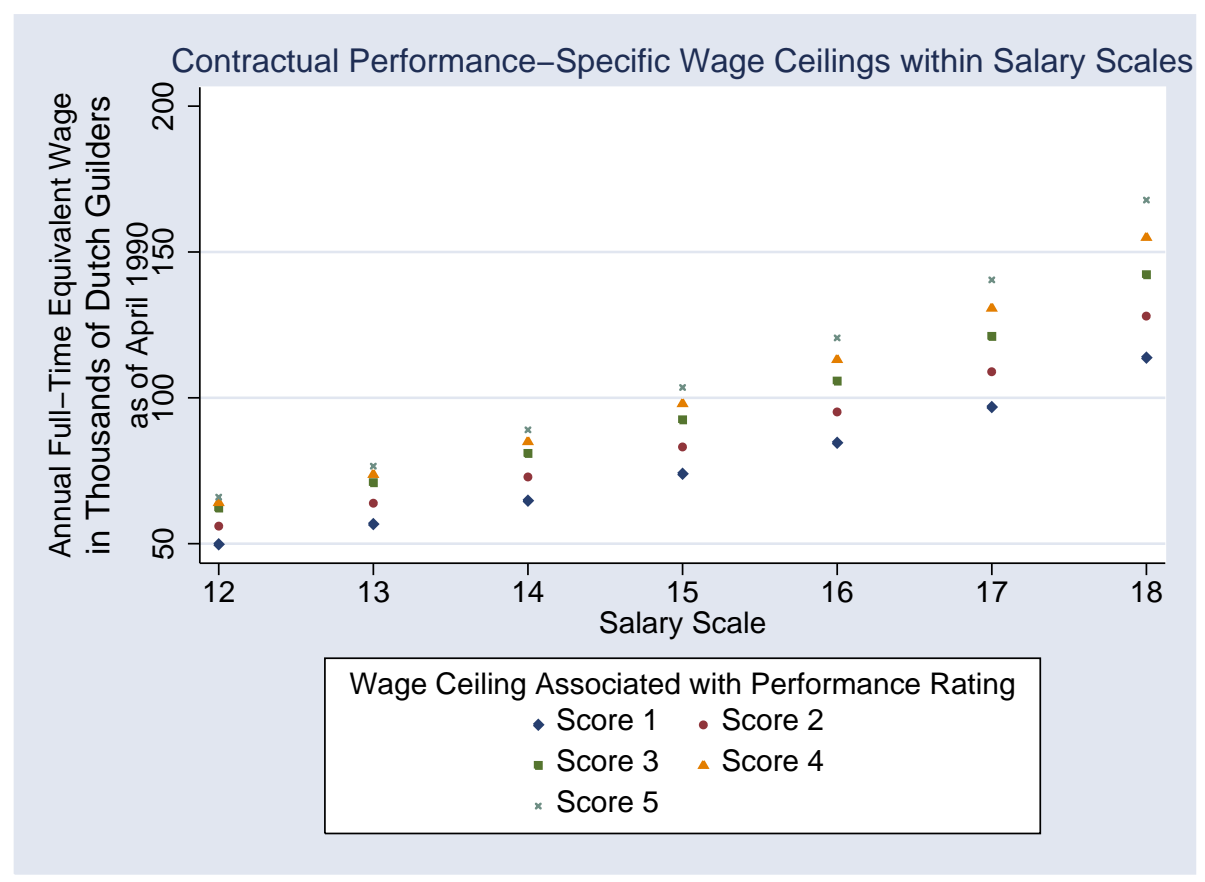

Notes: The Figure plots the performance rating-specific wage ceilings of contractual annual full-time equivalent wages in the different salary scales of the salary system for white-collar workers. A reference wage is defined for each salary scale which coincides with the wage ceiling for the median performance score. Wage ceilings associated with other ratings are defined as percentages of the reference wage. Wage ceilings for the lowest and the highest rating constitute respectively the minimum and maximum wages of a salary scale. 
Table 1: Descriptive Statistics

\begin{tabular}{|c|c|c|c|c|}
\hline & \multicolumn{4}{|c|}{ Means (Standard Deviations) } \\
\hline & $\begin{array}{l}\text { Blue-Collar } \\
\text { pooled }\end{array}$ & $\begin{array}{l}\text { White-Collar } \\
\text { pooled }\end{array}$ & $\begin{array}{l}\text { M/A sample } \\
\text { Company A }\end{array}$ & F/I sample \\
\hline Sample Size ${ }^{a}$ & 71012 & 24524 & 4788 & 10809 \\
\hline $\begin{array}{l}\text { Highest level of educational attainment: }{ }^{b} \\
\text { Basic Education (lo) } \\
\text { Lower vocational degree (vmbo) } \\
\text { Lower general schooling (vmbo theorie) } \\
\text { Apprenticeship (BBL) } \\
\text { Intermediate general schooling (havo) } \\
\text { Intermediate vocational degree (vmbo theorie) } \\
\text { Higher general schooling (vwo) } \\
\text { Higher Vocational degree (hbo) } \\
\text { University/Technical College } \\
\text { Education not reported }\end{array}$ & $\begin{array}{l}0.020 \\
0.182 \\
0.075 \\
0.255 \\
0.022 \\
0.172 \\
0.011 \\
0.015 \\
0.002 \\
0.247\end{array}$ & $\begin{array}{l}0.027 \\
0.032 \\
0.040 \\
0.015 \\
0.136 \\
0.046 \\
0.306 \\
0.192 \\
0.205\end{array}$ & & \\
\hline $\begin{array}{l}\text { Educational achievement compared: }{ }^{c} \\
\text { Less than high school } \\
\text { High school } \\
\text { Higher vocational/Bachelor's/Laurea } \\
\text { University (Master and Doctorate) }\end{array}$ & $\begin{array}{l}0.269 \\
0.709 \\
0.020 \\
0.002\end{array}$ & $\begin{array}{l}0.034 \\
0.339 \\
0.386 \\
0.242\end{array}$ & $\begin{array}{l}0.050 \\
0.449 \\
0.444 \\
0.056\end{array}$ & $\begin{array}{l}0.248 \\
0.583 \\
0.169 \\
0.00\end{array}$ \\
\hline $\begin{array}{l}\text { Tenure (years) } \\
\text { Pre-company experience (years) } \\
\text { Age (years) }\end{array}$ & $\begin{array}{c}10.6(8.8) \\
5.0(7.2) \\
35.3(9.7)\end{array}$ & $\begin{array}{l}14.0(9.8) \\
5.8(6.2) \\
41.0(8.3)\end{array}$ & $\begin{aligned} 16.8 & (10.4) \\
6.8 & (6.7) \\
43.1 & (10.5)\end{aligned}$ & $\begin{array}{r}16.4(8.3) \\
5.0(4.6) \\
40.7(8.5)\end{array}$ \\
\hline $\begin{array}{l}\text { Supervisors' evaluations: }{ }^{d} \\
\text { Performance rating } 1 \text { (=worst rating) } \\
\text { Performance rating } 2 \\
\text { Performance rating } 3 \\
\text { Performance rating } 4 \\
\text { Performance rating } 5 \\
\text { Performance rating } 6\end{array}$ & $\begin{array}{l}0.001 \\
0.013 \\
0.402 \\
0.423 \\
0.144 \\
0.017\end{array}$ & $\begin{array}{l}0.002 \\
0.038 \\
0.813 \\
0.143 \\
0.004 \\
-\end{array}$ & $\begin{array}{l}0.002 \\
0.053 \\
0.743 \\
0.202\end{array}$ & $\begin{array}{l}0.024 \\
0.125 \\
0.369 \\
0.483\end{array}$ \\
\hline $\begin{array}{c}\text { Job Level: }{ }^{e} \\
\text { Level } 1 \\
\text { Level } 2 \\
\text { Level } 3 \\
\text { Level } 4 \\
\text { Level } 5 \\
\text { Level } 6 \\
\text { Level } 7 \\
\text { Level } 8\end{array}$ & $\begin{array}{l}0.677 \\
0.223 \\
0.092 \\
0.008\end{array}$ & $\begin{array}{l}0.006 \\
0.092 \\
0.366 \\
0.255 \\
0.176 \\
0.061 \\
0.045\end{array}$ & & $\begin{array}{l}0.011 \\
0.034 \\
0.053 \\
0.202 \\
0.127 \\
0.236 \\
0.179 \\
0.156\end{array}$ \\
\hline
\end{tabular}

a. The samples for Fokker workers consist of ten cross-sections taken at the beginning of the year after ratings for the previous year performance have been given and annual wage raises been awarded. The M/A sample is their Company A sample which is described in M/A 1980. The F/I sample is described in F/I 2001.

$b$. The Dutch educational system consists of modules that can be followed consecutively (for more details see Hartog, Pfann, and Ridder, 1989). After having completed basic education (lo), which takes 6 years, it is possible to either follow a 4 year lower vocational schooling course to obtain the vmbo degree or to attend any of the school forms leading to a general schooling degree. Lower general education (vmbo theorie, 4 years) makes one eligible to pursue an intermediate vocational schooling degree (mbo, 1-4 years) or complete an apprenticeship (BBL, 1-4 years). An intermediate general schooling degree (havo, 5 years) is a prerequesite for higher vocational schooling (hbo, 4 years), while a higher general schooling degree (vwo, 6 years) is a prerequisite for pursuing a college or university degree. It is possible to pursue general education consecutively; similarly it is possible to enter the next higher level of vocational schooling after having completed vocational schooling at the level just below it, e.g. an intermediate vocational degree qualifies to enroll in higher vocational schooling.

c. The education categories are re-defined to ease comparison and the numbers for Fokker workers are based on the sub-sample with non-missing education. The category "less than high school" includes Fokker workers with education levels "lo" and "vmbo". The category "high school" includes Fokker workers with "mavo", "BBL", "havo", "vmbo theorie", and "vwo".

$d$. The performance assessment scale for blue-collar Fokker workers contains 6 categories (in ascending order: $1=$ falls behind, $2=$ unsatisfactory, $3=$ normal-good, $4=$ good-very good, $5=$ very good - outstanding, 6 = excellent). The evaluation scale for white-collar Fokker employees has 5 categories $(1=$ unsatisfactory, $2=$ satisfactory, $3=\operatorname{good}, 4=$ very good, $5=$ outstanding $) . \mathrm{M} / \mathrm{A}$ and $\mathrm{F} / \mathrm{I}$ report only 4 categories.

$e$. Job levels for Fokker are inferred from job transitions and are defined in Dohmen, Kriechel, and Pfann (2004). While blue-collar workers mainly occupy three job levels in the Fokker data, F/I report 8 levels for their non-managerial workers. The distribution across levels is not reported by $\mathrm{M} / \mathrm{A}$. 
Table 2: Nominal Wage Changes in the Salary System

\begin{tabular}{l|cc|cc}
\hline Date & $\Delta$ Wage $(\%)$ & $\Delta$ CPI $(\%)$ & Wage Index & CPI Index \\
\hline Jan 1, 1987 & & & 100.00 & 100.00 \\
Jul 1, 1987 & 0.50 & 0.11 & 100.50 & 100.11 \\
Jul 1, 1988 & 1.00 & 0.95 & 101.51 & 101.06 \\
Jan 2, 1989 & 1.00 & 0.10 & 102.52 & 101.17 \\
Apr 1, 1990 & 3.00 & 2.83 & 105.60 & 104.03 \\
Jan 1, 1991 & 0.75 & 1.83 & 106.39 & 105.93 \\
Jul 1, 1991 & 3.25 & 2.01 & 109.85 & 108.05 \\
Apr 1, 1992 & 4.00 & 2.45 & 114.23 & 110.70 \\
Jan 1, 1996 & 3.80 & 8.61 & 118.58 & 120.23 \\
\hline
\end{tabular}

Notes:

1. Column 1 reports the dates on which the firm raised all contractual wages by the percentage amount shown in column 2. These percentage nominal wage raises are contrasted in column 3 with the inflation rate over the period since the last nominal wage increase. The inflation rate is calculated based on percentage changes of the quarterly consumer price index provided by Statistics Netherlands. Cumulative changes can be read off the nominal wage and consumer price indices in columns 4 and 5 , which are calculated based on the information in the first columns.

2. Price compensations are deferred after April 1, 1992, until January 1, 1996. Otherwise, nominal wages would have been raised in four steps by $1.25 \%$ on May $1,1993,0.5 \%$ in October 1993, 0.5\% in February 1994, 0.75\% in February 1995, and 0.75\% in January 1996. Workers who were dismissed during the period received the accumulated deferred price compensation about four weeks prior to their dismissal. This made them eligible for higher social security benefits. The yearly inflation rate based on the consumer price index was steady at around 2\% from 1992 until 1996 when Fokker did not raise nominal contractual wages. 


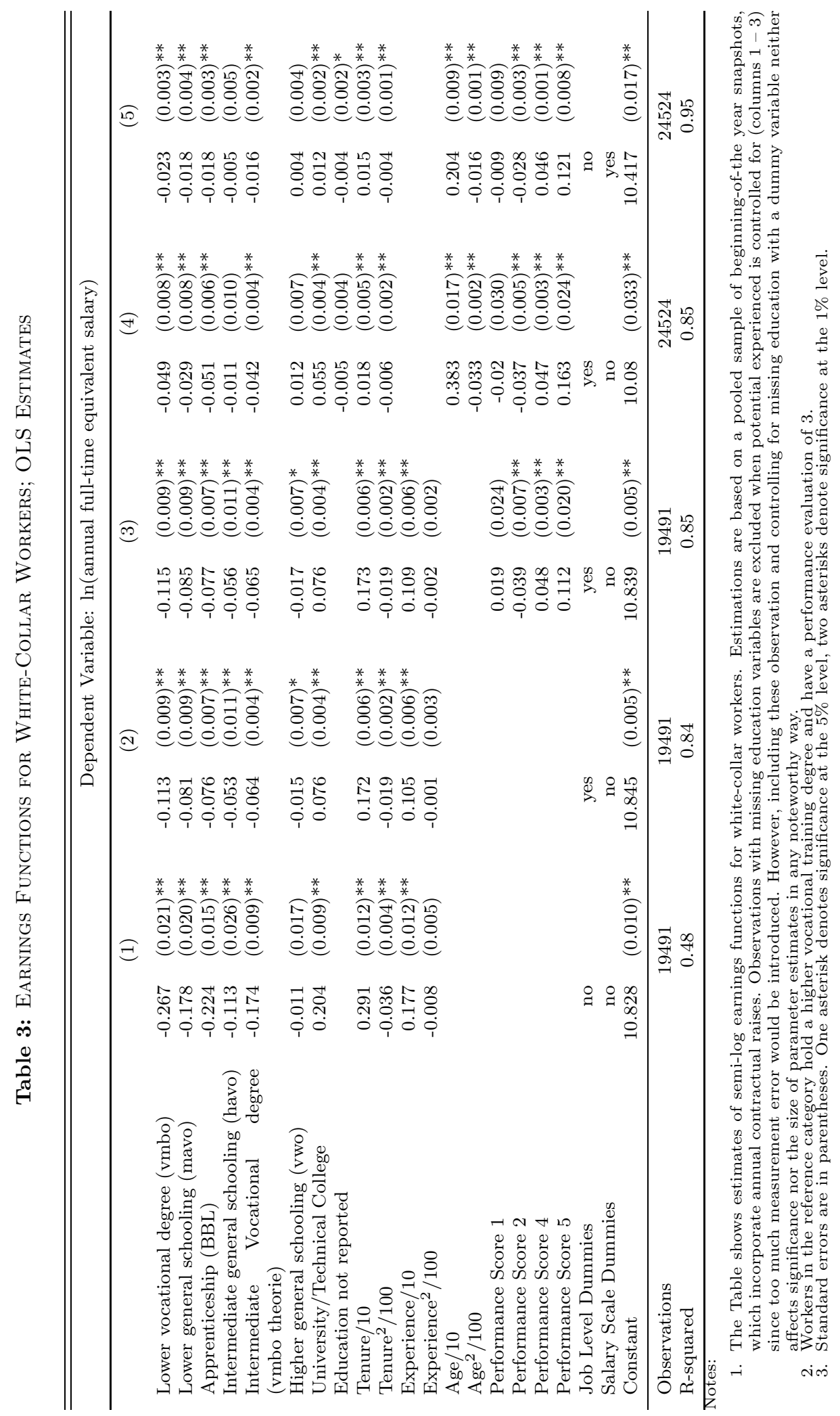




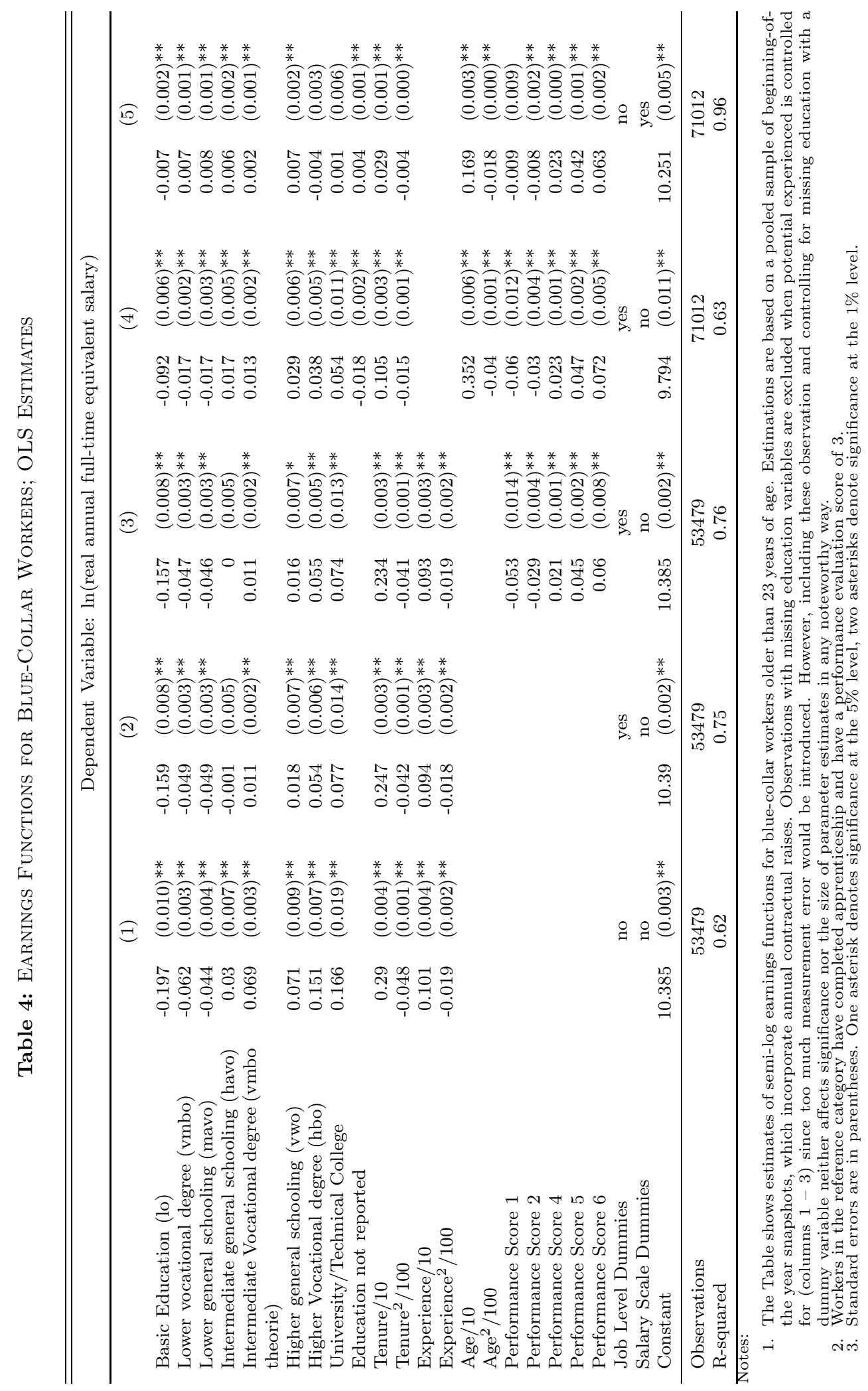


Table 5: Determinants of Upward Wage Scale Mobility; Probit Estimates

\begin{tabular}{lcccc}
\hline \hline \multicolumn{4}{c}{ Dependent Variable: Upward Transition (1 if yes, 0 if no) } \\
\hline & (Early & Transition) & (Late Transition) \\
Promotion Last Year & -0.127 & $(0.007)^{*}$ & 0.210 & $(0.014)^{*}$ \\
Performance Score 1 & -0.080 & $(0.177)$ & \multicolumn{2}{c}{ omitted } \\
Performance Score 2 & -0.130 & $(0.026)^{*}$ & -0.045 & $(0.016)$ \\
Performance Score 4 & 0.157 & $(0.007)^{*}$ & -0.002 & $(0.005)$ \\
Performance Score 5 & 0.176 & $(0.017)^{*}$ & -0.029 & $(0.006)$ \\
Performance Score 6 & \multicolumn{3}{c}{-0.048} & $(0.010)$ \\
Education Dummies & \multicolumn{2}{c}{ yes } & \multicolumn{2}{c}{ yes } \\
\hline Observations & \multicolumn{2}{c}{22297} & \multicolumn{2}{c}{25932}
\end{tabular}

Notes: The Table shows marginal effects evaluated at the mean of the explanatory variables of probit regressions for the probability of a transition to a higher wage scale in the bluecollar wage system. Results are based on pooled yearly cross sections taken after performance evaluations have been given and contractual wages have been awarded. The first column shows the estimation results on the sub-sample of workers who have not yet reached the highest grade of the current salary scale. Since the highest performance score has wages defined only in the highest grade, there are no observations in this cell. The second column shows the effect of performance on promotion for those workers who have reached the top of a salary scale. Since no worker with the lowest performance rating is ever promoted to a higher scale, their observations are ignored in the estimation as their performance score predicts their failure to be promoted perfectly. Workers with performance score 3 are in the reference group. Standard errors are in parentheses, an asterisk denotes significance at the $1 \%$ level. 


\section{IZA Discussion Papers}

\begin{tabular}{|c|c|c|c|c|}
\hline No. & Author(s) & Title & Area & Date \\
\hline 921 & $\begin{array}{l}\text { P. Egger } \\
\text { M. Pfaffermayr } \\
\text { A. Weber }\end{array}$ & $\begin{array}{l}\text { Sectoral Adjustment of Employment: The Impact } \\
\text { of Outsourcing and Trade at the Micro Level }\end{array}$ & 2 & $11 / 03$ \\
\hline 922 & $\begin{array}{l}\text { J. Merz } \\
\text { D. Burgert }\end{array}$ & $\begin{array}{l}\text { Working Hour Arrangements and Working Hours } \\
\text { - A Microeconometric Analysis Based on } \\
\text { German Time Use Diary Data }\end{array}$ & 5 & $11 / 03$ \\
\hline 923 & $\begin{array}{l}\text { U. Dulleck } \\
\text { P. Frijters } \\
\text { R. Winter-Ebmer }\end{array}$ & $\begin{array}{l}\text { Reducing Start-Up Costs for New Firms: The } \\
\text { Double Dividend on the Labour Market }\end{array}$ & 5 & $11 / 03$ \\
\hline 924 & $\begin{array}{l}\text { A. P. Damm } \\
\text { M. Rosholm }\end{array}$ & $\begin{array}{l}\text { Employment Effects of Dispersal Policies on } \\
\text { Refugee Immigrants, Part I: Theory }\end{array}$ & 1 & $11 / 03$ \\
\hline 925 & $\begin{array}{l}\text { A. P. Damm } \\
\text { M. Rosholm }\end{array}$ & $\begin{array}{l}\text { Employment Effects of Dispersal Policies on } \\
\text { Refugee Immigrants, Part II: Empirical Evidence }\end{array}$ & 1 & $11 / 03$ \\
\hline 926 & $\begin{array}{l}\text { S. E. Black } \\
\text { P. J. Devereux } \\
\text { K. G. Salvanes }\end{array}$ & $\begin{array}{l}\text { Why the Apple Doesn't Fall Far: Understanding } \\
\text { Intergenerational Transmission of Human } \\
\text { Capital }\end{array}$ & 5 & $11 / 03$ \\
\hline 927 & $\begin{array}{l}\text { L. Goette } \\
\text { D. Huffman } \\
\text { E. Fehr }\end{array}$ & Loss Aversion and Labor Supply & 5 & $11 / 03$ \\
\hline 928 & $\begin{array}{l}\text { H. Selod } \\
\text { Y. Zenou }\end{array}$ & $\begin{array}{l}\text { Does City Structure Affect the Labor-Market } \\
\text { Outcomes of Black Workers? }\end{array}$ & 3 & $11 / 03$ \\
\hline 929 & $\begin{array}{l}\text { Z. Eckstein } \\
\text { G. J. van den Berg }\end{array}$ & Empirical Labor Search: A Survey & 1 & $11 / 03$ \\
\hline 930 & $\begin{array}{l}\text { M. Lindeboom } \\
\text { F. Portrait } \\
\text { G. J. van den Berg }\end{array}$ & $\begin{array}{l}\text { Individual Mortality and Macro Economic } \\
\text { Conditions from Birth to Death }\end{array}$ & 3 & $11 / 03$ \\
\hline 931 & P. Kooreman & $\begin{array}{l}\text { Time, Money, Peers, and Parents: Some Data } \\
\text { and Theories on Teenage Behavior }\end{array}$ & 5 & $11 / 03$ \\
\hline 932 & $\begin{array}{l}\text { H. N. Mocan } \\
\text { E. Tekin }\end{array}$ & $\begin{array}{l}\text { Guns, Drugs and Juvenile Crime: Evidence from } \\
\text { a Panel of Siblings and Twins }\end{array}$ & 3 & $11 / 03$ \\
\hline 933 & $\begin{array}{l}\text { W. Arulampalam } \\
\text { A. L. Booth } \\
\text { M. L. Bryan }\end{array}$ & Training in Europe & 5 & $11 / 03$ \\
\hline 934 & $\begin{array}{l}\text { M. Piva } \\
\text { E. Santarelli } \\
\text { M. Vivarelli }\end{array}$ & $\begin{array}{l}\text { The Skill Bias Effect of Technological and } \\
\text { Organisational Change: Evidence and Policy } \\
\text { Implications }\end{array}$ & 5 & $11 / 03$ \\
\hline 935 & T. J. Dohmen & $\begin{array}{l}\text { Performance, Seniority and Wages: Formal } \\
\text { Salary Systems and Individual Earnings Profiles }\end{array}$ & 1 & $11 / 03$ \\
\hline
\end{tabular}

An updated list of IZA Discussion Papers is available on the center's homepage www.iza.org. 